\title{
水素吸蔵合金による水素貯蔵
}

\author{
布 浦 達 也 \\ 日本重化学工業株式会社 凿104-8257 東京都中央区新川 1-17-25
}

（2015 年 7 月 14 日受付；2015 年 9 月 20 日掲載決定）

\section{Hydrogen Storage Alloy}

\author{
Tatsuya FuURA \\ Japan Metals \& Chemicals Co., Ltd., 1-17-25 Shinkawa, Chuo-ku, Tokyo 104-8257
}

(Received July 14, 2015 ; Accepted September 20, 2015)

\begin{abstract}
Hydrogen attracts attention as clean energy of the next generation. In order to put a hydrogen energy system to practical use, the technical development of safe and efficient storage/transportation media is on of the most important subjects. Hydrogen storage tank which is under development can be classified into following types ; 1) high pressure hydrogen tank, 2) liquid hydrogen tank, 3) metal hydride storage tank and the other. In this paper, I provide the development status of recent "metal hydride storage tank".
\end{abstract}

KEYWORDS : hydrogen, hydrogen storage alloy, metal hydride

\section{1.は じめに}

2014 年 4 月に閣議決定された「エネルギー基本計 画」)では，エネルギー政策の基本的視点である $\lceil\mathrm{S}+3 \mathrm{E} 」$ の達成に向けた将来の二次エネルギーとして 電気, 熱に加え「水素」が中心的役割を担うことが期待 されるとされ，「水素社会」実現へ向けた取組が活発 化 ${ }^{2)}$ ている。水素は水や多様な一次エネルギー源から 製造でき, 貯蔵可能であることから, エネルギーの安全 保障のうえでも重要な二次エネルギーとして捉えられて いる。ただし, 常温で気体の水素をコンパクトに眝蔵す るためには, 圧縮, 液化, 合金への吸蔵, もしくはケミ カルハイドライドのように別の物質に変えて貯蔵する必 要がある。

本稿では, 水素貯蔵方式の一つである水素吸蔵合金 （MH）を用いた水素貯蔵の話題について提供する。

\section{2. 水素吸蔵合金の応用分野}

$\mathrm{MH}$ による水素貯蔵の最大の利点は, $1 \mathrm{MPa}$ 程度の比 較的低い圧力で, コンパクトな水素貯蔵が可能な点であ

E-mail : fuurat@jmc.co.jp
る。

Table 1 に各種の水素貯蔵密度について示すが, 代表 的な $\mathrm{MH}$ の一つである $\mathrm{LaNi}_{5} \mathrm{H}_{6}$ の水素貯蔵密度は 93 $\mathrm{g} / \mathrm{L}$ であり, $20 \mathrm{~K}$-大気圧状態の液化水素の $70 \mathrm{~g} / \mathrm{L}$ を超 える密度を有する。MH 容器には粉体の状態で充填され るので, MH 容器としての水素充填密度は材料の半分程 度の $50 \mathrm{~g} / \mathrm{L}$ となるが，この值は圧縮ガスでは，100 MPa の圧力に相当する。一方, 欠点としては, 重量貯蔵密度 が数 \% 程度と重量当たりの水素吸蔵量が少ない点であ る。

MH の開発当初は, 水素貯蔵タンク, ヒートポンプ, 水素の精製等の用途が検討されていたが，現在までに， 実用化されている唯一の応用分野は, $\mathrm{Ni}$-水素電池の負 極材料である。1990 年の初期に, 電池メーカーにより 製造販売が開始され, 電動工具, 家庭用等の 2 次電池, ハイブリッド自動車等に利用されている

MH は，単体で水素化物を形成しやすい元素 $\mathrm{A}$ と遷 移金属等の水素化物を形成しない元素 $\mathrm{B}$ との組み合わ せからなる金属間化合物 $\left(\mathrm{A}_{2} \mathrm{~B}, \mathrm{AB}, \mathrm{AB}_{2}, \mathrm{AB}_{5}\right)$ や $\mathrm{TiCrV}$ 合金等の固溶体合金に大別される。Table 2 に代 表的な MH の組成例を示す。

電池用の合金としては, 容量の大きな $\mathrm{Ti}$ 系の $\mathrm{AB}_{2}$ 系 
Table 1. Hydrogen density.

\begin{tabular}{|c|c|}
\hline & Hydrogen density $\left(\mathrm{g}-\mathrm{H}_{2} / \mathrm{L}\right)$ \\
\hline Hydrogen gas (0.9 MPa) & $0.74\left(\mathrm{~g}-\mathrm{H}_{2} / \mathrm{L}\right)$ \\
\hline Hydrogen gas (35 MPa) & $23\left(\mathrm{~g}-\mathrm{H}_{2} / \mathrm{L}\right)$ \\
\hline Hydrogen gas (70 MPa) & $39\left(\mathrm{~g}-\mathrm{H}_{2} / \mathrm{L}\right)$ \\
\hline Liquid hydrogen $(20 \mathrm{~K})$ & $70\left(\mathrm{~g}-\mathrm{H}_{2} / \mathrm{L}\right)$ \\
\hline Methylcyclohexane $\mathrm{C}_{7} \mathrm{H}_{14}$ & $47\left(\mathrm{~g}-\mathrm{H}_{2} / \mathrm{L}\right)$ \\
\hline $\mathrm{LaNi}_{5} \mathrm{H}_{6}$ & $93\left(\mathrm{~g}-\mathrm{H}_{2} / \mathrm{L}\right)$ \\
\hline
\end{tabular}

Table 2. Metal hydride.

\begin{tabular}{ccccc}
\hline Fomula & $\begin{array}{c}\text { Hydrogen } \\
\text { content } \\
\text { (mass\%) }\end{array}$ & $\begin{array}{c}\text { Hydrogen } \\
\text { density } \\
\left(\mathrm{g}-\mathrm{H}_{2}-\mathrm{L}\right)\end{array}$ & $\begin{array}{c}\Delta \mathrm{H} \\
\left(\mathrm{kJ} / \mathrm{mol} \mathrm{H}_{2}\right)\end{array}$ & Temparature \\
\hline $\mathrm{LaNi}_{5}$ & 1.4 & 93 & -30 & Room temp. \\
$\mathrm{TiMn}_{1.5}$ & 1.8 & 95 & -28 & Roon temp. \\
$\mathrm{Mg}_{2} \mathrm{Ni}$ & 3.6 & 97 & -64 & $673 \mathrm{~K}$ \\
\hline
\end{tabular}

合金が検討されたこともあったが，現在，量産されてい る合金系は，電解液中での耐食性・初期活性・高率放 電・サイクル特性等を満足する合金として, A 側元素と して希土類，B 側元素として Ni を主成分とした合金系 が採用されている。

水素䝪蔵用途としては, 気固相での反応となるため, 希土類と $\mathrm{Ni}$ の合金系に限らず， $\mathrm{Mg}$ 系の合金， Ti 系の 合金等も用途や作動温度に応じて検討がされている。電 池用途以外については, 現時点で量産段階には至ってい ないが，これまで様々な取り組みがなされてきた。

現在発売されている燃料電池自動車には，重量を軽く できる $70 \mathrm{MPa}$ の高圧複合容器 ${ }^{5}$ が採用されているが, 1990 年代には, 水素貯蔵タンクとして水素吸蔵合金夕 ンク ${ }^{6}$ 液化水素タンク7の採用が検討されていた。し かし, MH は重量, 液化水素は蒸発によるロスの発生が 欠点とされ，実用化には至らなかった。

そこで，MH の欠点である重量を改善するために，軽 量な高圧容器とコンパクトな水素䝪蔵が可能な MH を 組み合わせた Hybrid Tank が提案された8,9)。我々も, NEDO の委託事業において, 軽量・コンパクトな水素 䝪蔵夕ンクを目指し，高圧複合容器 $(35 \mathrm{MPa})$ と, $\mathrm{MH}$ を組み合わせた Hybrid Tank の開発に取り組んだ ${ }^{10,11)}$ 。 開発した Hybrid Tank の写真を Fig. 1 に示す。

システムでの体積貯蔵密度は $30 \mathrm{~g} / \mathrm{L}\left(5 \mathrm{~kg}-\mathrm{H}_{2} / 166 \mathrm{~L}\right)$ と $70 \mathrm{MPa}$ の高圧容器を上まわる䝪蔵密度 $25 \mathrm{~g} / \mathrm{L} （ 5 \mathrm{~kg}-$ $\mathrm{H}_{2} / 200 \mathrm{~L}$ ）を達成できたが，一方で，システムでの重量 貯蔵密度は $2 \mathrm{wt} \%\left(5 \mathrm{~kg}-\mathrm{H}_{2} / 250 \mathrm{~kg}\right)$ であり, 車載用途 として実用化するには，水素䝪蔵材料のさらなる高容量 化が必要とされている。

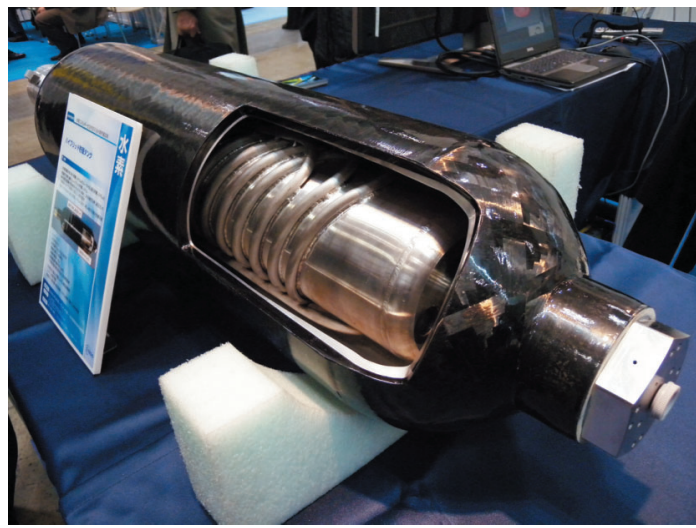

Fig. 1. (color online). Hybrid Tank (MH + 35MPa Type3).

\section{3. 水素吸蔵合金容器}

車載用途以外の MH 容器の採用例について紹介する。 平成 14 年度から経済産業省が害施した水素・燃料電池 実証プロジェクト（JHFC）で，液化水素と圧縮水素の 両方を供給できる液化水素型の水素ステーションが建設 され，昭和シェル石油，岩谷産業らによって運用・実証 が行われた ${ }^{12)}$ 。液化水素は, 真空断熱の 2 重構造容器内 に貯蔵されるが，外気からの入熱によって蒸発（ボイル オフ）し，タンク内圧が上昇する。常用圧力を超えない よう，ボイルオフガス（以下 BOG）を逃がす必要があ るが，BOG を大気中へ放出せずに $\mathrm{MH}$ へ回収し，回収 した水素を圧縮機へ供給する用途に，水素吸蔵合金容器 が採用された。 MH を採用するメリットとしては，低圧 で発生する BOG をコンパクトに回収できることであ る。

導入した水素吸蔵合金容器のスペックを Table 3 に, 写真を Fig. 2 に示す。回収した水素は, 圧縮機へ供給す るため, 一定圧力, 一定流量で供給する必要があり, 放 出時の性能スペックの方が厳しい条件であった。 $\mathrm{MH}$ 容 器の設計は, 放出時の性能要件を満たすよう熱交換器の 設計を実施した。

Fig. 3 に単体 $\left(5 \mathrm{Nm}^{3}\right)$ の MHTank の水素放出特性試 験の結果を示す。 $70^{\circ} \mathrm{C}$ の熱媒をコントロールすることに より，供給圧力の $0.8 \mathrm{MPa}$ を維持しつつ，一定流量で水 素を供給可能な性能を有する。このように MH の放出 時は, 吸熱反応を伴うため, 反応熱量に応じた熱の供給 が必要である。また， MH の平衡圧力が供給圧力以上と なるように MH 充填層の温度を維持する必要があり, 必要な吸蔵速度, 放出速度を得るには, MH 容器の熱交 換器性能が重要である。 
Table 3. Specification of the MH tank for BOG recovery.

\begin{tabular}{lr}
\hline & \multicolumn{1}{c}{ Specification } \\
\hline Hydrogen storage volume & $40 \mathrm{Nm}^{3}$ \\
The mass of MH & $360 \mathrm{~kg}$ \\
Hydrogen pressure at absorption & $0.3 \mathrm{MPa}\left(@ 10^{\circ} \mathrm{C}\right)$ \\
The flow rate at absorption & $\mathrm{Max} 5 \mathrm{Nm}^{3} /$ hour. \\
Hydrogen pressure at desorption & $0.8 \mathrm{MPa}\left(@ 60^{\circ} \mathrm{C}\right)$ \\
The flow rate at desorption & $20 \mathrm{Nm}^{3} /$ hour \\
\hline
\end{tabular}

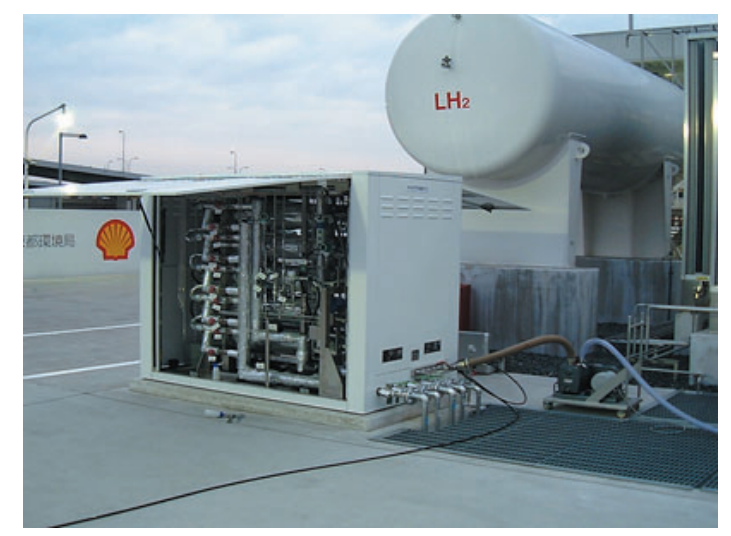

Fig. 2. (color online). MH Tank.

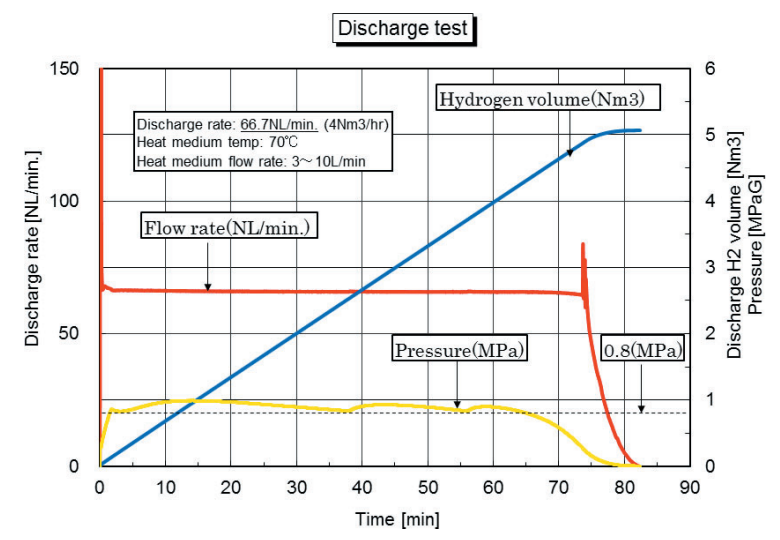

Fig. 3. (color online). Hydrogen discharge test.

\section{MH の反応シミュレーション}

$\mathrm{MH}$ の水素吸蔵時の反応は発熱, 放出時には吸熱反応 を伴う。MH は吸蔵・放出を繰り返すと微粉化が進行 し, 微粉末の充填層となることから, 有効熱伝導率は 1 $\mathrm{W} / \mathrm{m} / \mathrm{K}$ と非常に小さい ${ }^{13)}$ 。そのため, 伝熱過程が律速 過程となり反応が進行する。したがって, 非定常熱伝導 方程式を解くことにより MH の吸蔵・放出時のシミュ レーションが可能である ${ }^{14)}$ 。支配方程式を(1)〜 (4)に 示す。

\section{主要記号}

$T$ : 温度 $\left[{ }^{\circ} \mathrm{C}\right]$

$\rho: \mathrm{MH}$ の充填密度 $\left[\mathrm{kg} / \mathrm{m}^{3}\right]$

$C p: \mathrm{MH}$ の比熱 $[\mathrm{J} / \mathrm{kg} / \mathrm{K}]$

$C:$ 水素組成比 $[\mathrm{H} / \mathrm{M}]$

$P$ : 圧力 $[\mathrm{MPa}]$

$P e: \mathrm{MH}$ の平衡水素圧力 $[\mathrm{MPa}]$

$\Delta h:$ 水素化物生成エンタルピ $\left[\mathrm{J} / \mathrm{mol} \mathrm{H}_{2}\right]$

$\lambda: \mathrm{MH}$ 充填層の見かけの熱伝導率 $[\mathrm{W} / \mathrm{m} / \mathrm{K}]$

$q^{\prime \prime \prime}$ : 単位時間, 単位体積あたりの反応熱 $\left[\mathrm{J} / \mathrm{m}^{3} / \mathrm{sec}\right.$. $]$

$\phi$ : 水素化反応速度 $\left[\mathrm{mol} \mathrm{H} / \mathrm{m}^{3} / \mathrm{sec}\right.$. $]$

温度場の支配方程式（2 次元非定常熱伝導方程式）

$$
C_{p} \rho \frac{\partial T}{\partial t}=\frac{\partial}{\partial x}\left(\lambda \frac{\partial T}{\partial x}\right)+\frac{\partial}{\partial y}\left(\lambda \frac{\partial T}{\partial y}\right)+q^{\prime \prime \prime}
$$

濃度場の支配方程式（反応速度）

$$
\frac{d C(x, y, t)}{d t}=k \cdot\left(P-P_{e}(T, C)\right)
$$

反応熱量

$$
q^{\prime \prime \prime}(x, y, t)=\Delta h \cdot \phi(x, y, t)
$$

合金の平衡圧力

$$
P_{e q}=\phi(T, C)
$$

Fig. 1 の Hybrid Tank の開発を実施していた際のシミ ユレーション結果と実験結果の一例を示す。Fig. 4 に高 圧容器内の MH Cartridge の断面を示す。容器外壁に巻 きつけた熱媒管を通して, Cartridge の胴部, MH 充填層 内に設けた $\mathrm{Al}$ 製の伝熱フィンを通して $\mathrm{MH}$ の反応熱の 除去，供給を行う構造となっている。

Fig. 4 の図は吸蔵途中の水素吸蔵状態を示した図であ るが, 冷却面に近い部分より水素の吸蔵が進んでいる （濃淡の濃い部分が吸蔵している）ことが確認できる。

供給圧力と $\mathrm{MH}$ の平衡圧力に十分な圧力差がある場 合には, 水素の充填を開始すると, MH 充填層全体が, 平衡となる温度まで水素を吸蔵し, $\mathrm{MH}$ 充填層の温度が 上昇する。その後は, 冷却面に近い部分から水素の吸蔵 が進み, 反応面が冷却面から離れた容器中心部へ移行し ながら反応が進行する。

Fig. 5 に水素の吸蔵試験の結果とシミュレーション結 果を示す。温度履歴については, 実験結果とシミュレー ション結果に差異がみられる。これは MH 充填層内に 設置した熱電対と $\mathrm{MH}$ の接触状態が悪く, $\mathrm{MH}$ 充填層の 温度を正しく測定できていなかったことが原因と思われ る。

一方で, 水素充填量の推移については, 実験結果とシ ミュレーション結果は同等な傾向を示しており, 非定常 熱伝導方程式を数值的に解くことにより, 水素充填性 


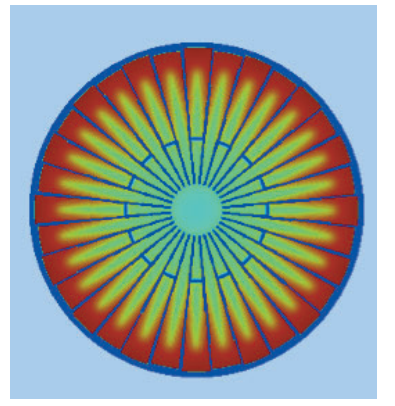

Fig. 4. (color online). Section model of $\mathrm{MH}$ cartridge. $(r-\theta$ coordinate system)

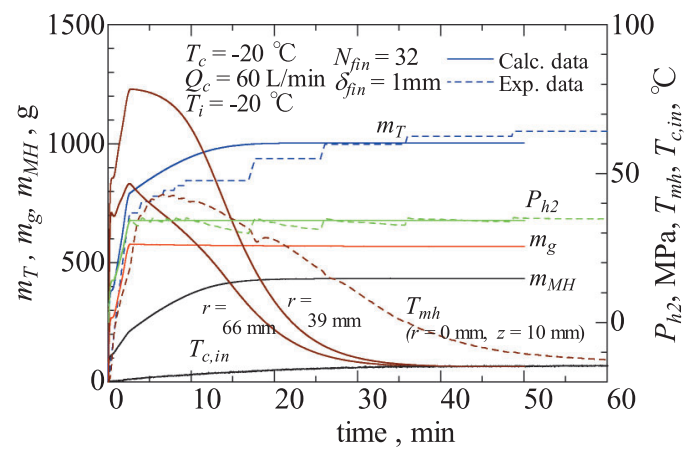

Fig. 5. (color online). Hydrogen absorption characteristics.

能，水素放出性能を予測できることがわかる。

\section{5. ま と め}

これまでにも, 水素は工業的には利用されてきたが, 水素をエネルギーとして利活用する「水素社会」の実現 には，まだ多くの課題解決および時間が必要と考えられ る。しかし, 昨今の異常気象による災害発生が, 地球温 暖化による影響だとすると, 持続可能な社会構築のため に, $\mathrm{CO}_{2}$ 削減の取組を進めていかなければならない。

水素に関していえば, 水素製造段階から, 輸送, 貯 蔵, 使用段階までを含めた効率の向上が, 今後, 重要と なると考えている。水素の賩蔵方式は，それぞれ一長一 短の特徵を有しているが，それぞれの特徴を活かし適材
適所で睁蔵方式の選択がされると思われる。

その一つの方式として, 安全性に優れ, コンパクトに 水素を眝蔵可能な $\mathrm{MH}$ 容器の実用化が進展することに 期待したい。

\section{謝 辞}

本研究の一部は独立行政法人 新エネルギー・産業技 術総合開発機構（NEDO）の委託業務の結果得られたも のであり，関係各位に樑く感謝申し上げます。

\section{文献}

1) 資源エネルギー仃 : エネルギー基本計画 (2014).

2) NEDO : NEDO 水素エネルギー白書 (2014).

3) 大角泰章: “水素吸蔵合金一その物性と応用一” ( グネ技術センター, 1993).

4）田村英雄: “水素吸蔵合金一基礎から最先端技術まで 一” (エヌ・ティー・エス, 1998).

5) http://www.toyota.co.jp/jpn/sustainability/environ ment/ecopro/2014/pdf/zero/hydrogen_tank. pdf

6) http://www2.mazda.com/ja/publicity/release/1997/ 9712/971203.html

7) 水素・燃料電池実証プロジェクト (JHFC) プロジェ クト参加車両, GM Hydrogen3.

8) 森 大五郎, 祓川徳彦, 篠澤民夫, 松永朋也, 藤敬司, 藤田勝義: 日本機械学会論文集 (B 編) 73, 1236 (2007).

9) 藤田勝義, 久保秀人, 藤 敬司 : 燃料電池 7, 73 (2008).

10） NEDO : NEDO 成果報告書「水素安全利用等基盤技 術開発一車両関連機器に関する研究開発一水素貯蔵 合金と超高圧容器を組み合わせたハイブリッド貯蔵 タンクの研究開発」平成 17 年度〜平成 19 年度, 平 成 20 年 3 月 (2008).

11) NEDO : NEDO 成果報告書「水素製造・輸送・眝蔵 システム/システム技術開発/車載等水素賩蔵・輸送 容器システム技術開発に関する研究開発」平成 20 年度 平成 22 年度, 平成 23 年 3 月 (2011).

12) http://www.jari.or.jp/portals/0/jhfc/station/kanto/ img/ariake_p. jpg

13) 門出政則, 光武雄一: 日本機械学会論文集 (B 編) 70, 3264 (2004).

14) 光武雄一, 門出政則, 重高健吾, 角掛 繁, 布浦達也 : 日本機械学会論文集 (B 編) 72, 1645 (2006). 